\title{
Acidic stress caused by dietary administration of citric acid in broiler chickens
}

\author{
R. Nourmohammadi and H. Khosravinia \\ Department of Animal Sciences, Lorestan University, Khorramabad, Lorestan, Iran \\ Correspondence to: R. Nourmohammadi (nourmohammadi.61@gmail.com)
}

Received: 19 March 2015 - Revised: 2 July 2015 - Accepted: 17 July 2015 - Published: 31 July 2015

\begin{abstract}
Citric acid (CA) is commonly used in poultry diets to promote growth by acidifying the gastrointestinal contents, improving nutrient digestibility, and reducing pathogen loads; therefore, this study was conducted to demonstrate the effects of 0,30 and $60 \mathrm{~g}$ of CA per kilogramme of diet on productive performance, selected blood metabolites, immune response and certain gut-related variables in broiler chickens using 150, 7-day-old Ross 308 male broiler chicks in five replicates of 10 birds each per diet. Growth performance, daily feed intake and tibia phosphorous $(\mathrm{P})$ retention were significantly improved by the diets containing $30 \mathrm{~g} \mathrm{~kg}^{-1}$ of CA $(P<0.01)$ but were suppressed as CA increased to $60 \mathrm{~g} \mathrm{~kg}^{-1}$. Dietary CA increased proventriculus, gizzard and ileum percentage and villus length, crypt depth and goblet cell number in duodenum, jejunum and ileum as well as ileal digestibility of crude protein, apparent metabolisable energy and total phosphorus while it decreased the $\mathrm{pH}$ of contents in the gut segments concerned $(P<0.01)$. Diets containing $60 \mathrm{~g} \mathrm{~kg}^{-1}$ of CA significantly reduced plasma $\mathrm{P}$ and Fe levels as well as cholesterol level and Alkaline phosphatase activity $(P<0.05)$ while increasing the aspartate aminotransferase and lactate dehydrogenase activities $(P<0.01)$ in the blood serum of the birds at day 42 of age. The percentage of bursa and thymus was greater in the birds fed on diets containing 60 and $30 \mathrm{~g} \mathrm{~kg}^{-1}$ of CA, respectively $(P<0.01)$. It was concluded that inclusion of $60 \mathrm{~g} \mathrm{~kg}^{-1}$ of CA in the diet resulted in a severe reduction in performance, nutrient digestion and absorption and liver dysfunctions in broiler chickens, a phenomenon we call as acidic stress.
\end{abstract}

\section{Introduction}

Organic acids are presently well recognised as non-antibiotic feed additives in poultry nutrition (Windisch et al., 2008). These compounds are primarily used to prevent pathogen contamination such as Salmonella through sanitising the feed (Thompson and Hinton, 1997). However, experimental results showed that organic acids act to improve nutrient digestion and absorption, mucosal immunity and exert topical effects on the intestinal brush border in broiler chickens (Viveros et al., 2002). Kirchgessner and Roth (1982) reported that particular organic acids increase pepsin proteolysis secretion and enhance the release of gastrin and cholecystokinin hormones which regulate the digestion and absorption of proteins.

Citric acid (CA) is the most common organic acid used in poultry diets. It acts as a growth promoter through acidifying the gastrointestinal (GI) content and is considered as a favoured determinant in effective nutrient digestion. In addition, CA also improves the solubility of the feed ingredients, digestion and absorption of nutrients by modifying intestinal pH, (Centeno et al., 2007). Viveros et al. (2002) showed that dietary administration of acidifiers decreases the population of pathogenic bacteria and alters the nutrient uptake in favour of the host.

The first report, in the relevant literature, on administration of CA to animal diets was Shohl (1937), showed that rickets was prevented in rats fed a CA-/sodium citrate-supplemented diet deficient in $\mathrm{Ca}$ and $\mathrm{P}$. The data lay dormant for almost 20 years until Pileggi et al. (1956) examined the effects of dietary organic acids in rats and showed that some compounds resulted in better performance while others had no positive effect. During the last 50 years, an increasing number of reports on the use of organic acids have appeared in the literature. As a result, organic acids such as lactic, propionic, 
Table 1. The ingredients and chemical composition of the basal diets $\left(\mathrm{g} \mathrm{kg}^{-1}\right.$, as fresh matter).

\begin{tabular}{lcc}
\hline & $\begin{array}{c}\text { Grower } \\
\text { (7 to 21 days) }\end{array}$ & $\begin{array}{c}\text { Finisher } \\
\text { (22 to 42 days) }\end{array}$ \\
\hline Ingredients $\left(\mathrm{g} \mathrm{kg}^{-1}\right)$ & & \\
Corn & 57.00 & 58.60 \\
Soybean meal & 33.10 & 30.00 \\
Fish meal & 3.40 & 3.50 \\
Soybean oil & 2.00 & 3.50 \\
Dicalcium phosphate & 1.55 & 1.10 \\
Oyster shell & 1.03 & 1.18 \\
DL-Methionine & 0.01 & 0.01 \\
Salt & 0.26 & 0.26 \\
Sand & 0.65 & 0.85 \\
Trace minerals mix & 0.50 & 0.50 \\
Vitamins mix & & 0.50 \\
Calculated analysis & 0.50 & \\
Metabolisable energy $\left(\mathrm{MJ} \mathrm{kg}^{-1}\right)$ & 12.2 & 12.7 \\
Available phosphorus $\left(\mathrm{g} \mathrm{kg}^{-1}\right)$ & 4.5 & 3.6 \\
Lysine $\left(\mathrm{g} \mathrm{kg}^{-1}\right)$ & 11.0 & 10.0 \\
Methionine $\left(\mathrm{g} \mathrm{kg}{ }^{-1}\right)$ & 5.0 & 3.8 \\
Analysed composition $\left(\mathrm{g} \mathrm{kg}^{-1}\right)$ & & \\
Crude protein $(\mathrm{N} \times 6.25)$ & 21.00 & 19.00 \\
Calcium & 9.5 & 9.0 \\
Total phosphorus & 12.3 & 10.6 \\
\hline
\end{tabular}

a Mineral mix supplied per kilogramme diet: Mn, $55 \mathrm{mg} ; \mathrm{Zn}, 50 \mathrm{mg}$; Fe, $80 \mathrm{mg}$; Cu, $5 \mathrm{mg}$; Se, $0.1 \mathrm{mg}$; I, $0.18 \mathrm{mg}$.

b Vitamins mix supplied per kilogramme diet: vitamin A, $18000 \mathrm{IU}$; vitamin $\mathrm{D}_{3}, 4000 \mathrm{IU}$; vitamin $\mathrm{E}, 36 \mathrm{mg}$; vitamin $\mathrm{K}_{3}, 4 \mathrm{mg}$; vitamin $\mathrm{B}_{12}, 0.03 \mathrm{mg}$; thiamine, $1.8 \mathrm{mg}$; riboflavin, $13.2 \mathrm{mg}$; pyridoxine, $6 \mathrm{mg}$; niacin, $60 \mathrm{mg}$; calcium pantothenate, $20 \mathrm{mg}$; folic acid, $2 \mathrm{mg}$; biotin, $0.2 \mathrm{mg}$; choline chloride, $500 \mathrm{mg}$.

fumaric, malic and in particular CA are becoming widely accepted as non-antibiotic feed additives (Windisch et al., 2008) and are used as growth promoters in diets for pigs, chickens and rabbits (Islam, 2012). The mode of action of dietary organic acids, including CA, is mainly believed to rely on their ability to acidify the diet and ultimately the contents of the digestive tract (Boling et al., 2000). The recommended level for CA inclusion in poultry diets were confined to 0.5 to $1.5 \%$ in the pioneer research. Indeed, early reports suggested low dietary levels of CA, but the recommended level has gradually increased to $2 \%$ (Brenes et al., 2003), $2.5 \%$ (Centeno et al., 2007), $3 \%$ (Aydin et al., 2010), $4 \%$ (Esmaeilipour et al., 2011), $5 \%$ (Salgado-Tránsito et al., 2011) and even higher levels of $6 \%$ (Nourmohammadi et al., 2012) and $7.5 \%$ (Islam, 2012) of the poultry diets. Despite inconsistent results, it was concluded that CA at the dietary levels of 1 to $3 \%$ promotes productive performance and gut health in broiler chickens (Boling et al., 2000; Boling-Frankenbach et al., 2001).

To exhibit the above mentioned beneficial effects, CA is mostly included in broiler diets at doses ranging from 5 to $30 \mathrm{~g} \mathrm{~kg}^{-1}$ (Anjum and Chaudhry, 2010; Islam, 2012). Experimental results of dietary administration of CA at increasing levels in the broiler chicken had confusing results with some results supporting the increased levels of CA in broiler diets while others did not. This study was conducted to compare the effects of dietary CA at a high dose of $60 \mathrm{~g} \mathrm{~kg}^{-1}$ to the conventional level of $30 \mathrm{~g} \mathrm{~kg}^{-1}$ of diet, considering the assessment of a wide range of variables which are prone to alter when broiler chickens receive an acidified diet.

\section{Materials and methods}

\subsection{Experimental flock}

All procedures for this trial were conducted according to the guidelines of the Iranian Council of Animal Care (1995). One hundred and fifty one-day-old Ross 308 male broiler chicks were obtained from a commercial hatchery (Jonobekhorasan Ross Breeders Co., South Khorasan, Iran) and housed in a concrete floor house. The chicks were fed a typical commercial broiler starter mash ration for the first 6 days prior to the start of the experiment. The starter diet was cornsoybean meal-based and contained $3025 \mathrm{kcal}$ metabolisable energy $\mathrm{kg}^{-1}$ and $230 \mathrm{~g}$ crude protein $\mathrm{kg}^{-1}$. At day 7 , the birds were weighed individually, and chicks with an average weight of $135 \pm 5 \mathrm{~g}$ were assigned to 15 floor pens (10 birds pen ${ }^{-1}$ ) arranged in an open-sided partially controlled house. The ambient temperature was maintained at $32 \pm 1{ }^{\circ} \mathrm{C}$ in the first day and gradually decreased to $22^{\circ} \mathrm{C}$ by day 21 of age. Light was provided continuously during the study. The experimental period was divided into two phases: a grower phase (7 to 21 days) and a finisher phase (22 to 42 days). Basal diets for both phases were formulated to meet all nutrient recommendations published in the Ross rearing guideline (Table 1; Aviagen, 2011).The diets supplemented with either 30 or $60 \mathrm{~g} \mathrm{~kg}^{-1}$ of CA in the monohydrated form with $99.5 \%$ purity (Kimia Gharb Gostar, Kermanshah, Iran) were fed. Feed in the form of mash and water were supplied to the birds using a tube feeder and a manual waterer in each pen, respectively, for ad libitum consumption throughout the experimental period.

\subsection{Data collection}

Body weight (BW) and feed intake (FI) were recorded penwise weekly and were used to calculate data on daily weight gain (DWG), daily feed intake (DFI) and feed: gain (F:G) ratio. Mortality was recorded on a daily basis. At day 30 of age, titanium oxide $\left(1 \mathrm{~g} \mathrm{~kg}^{-1}\right.$ of diet) was added to all diets for 5 days and was used as an analytical marker to determine the effect of treatments on the ileal digestibility of crude protein (CP), apparent metabolisable energy (AME), calcium (Ca) and total phosphorous (tP). At day 35 of age, three birds per replicate ( 15 chicks per treatment) were randomly taken, weighed and slaughtered to collect the ileal contents. The ileum was defined as the segment of small intestine which extended from Meckel's diverticulum to $40 \mathrm{~mm}$ proximal to the ileocaecal junction. The ileum samples were placed into plastic containers and freeze-dried. The samples were grounded to pass through a $0.5 \mathrm{~mm}$ sieve before chemical analysis. 
At day 42, two randomly chosen birds per replicate (10 birds per treatment) were killed by cutting the carotid artery and jugular vein, and processed manually. The proventriculus, gizzard, and relative intestine weight (RIW), relative jejunum length (RJL), relative ileum length (RIL), and bursa and thymus percentage were measured. One gram of the digesta were immediately collected from the crop, gizzard, duodenum, jejunum and ileum of each bird and placed into clean $5 \mathrm{~mL}$ Falcon tubes (Becton Dickinson Vacutainer Systems, Franklin Lakes, NJ, USA). The samples were mixed with deionised water $\left(1: 10 \mathrm{wt} \mathrm{vol}^{-1}\right)$, and the $\mathrm{pH}$ of the solution was measured using a digital $\mathrm{pH}$ meter (Model 827, Metrohm, Herisau, Switzerland) at room temperature.

Blood samples were collected from two samples of the killed birds in non-heparinised tubes and kept on ice slashes until they were subjected to serum collection by centrifuging the whole blood sample at $3000 \mathrm{rpm}$ for $15 \mathrm{~min}$. The heparinised plasma separated from the blood samples taken from the same birds at the time of killing was stored at $-20^{\circ} \mathrm{C}$ in $1.5 \mathrm{~mL}$ Eppendorf tubes (Fisher HealthCare, Houston, TX, USA) for subsequent analyses. The serum samples were analysed for selected blood metabolites (urea, cholesterol, triglycerides and total protein), plasma mineral concentrations ( $\mathrm{Ca}, \mathrm{P}, \mathrm{Mg}, \mathrm{Fe}$ and $\mathrm{Zn}$ ) and the activity of alkaline phosphatase (ALP, EC 3.1.3.1) alanine aminotransferase (ALT, EC 2.6.1.2) aspartate aminotransferase (AST, E.C.2.6.1.1) and lactate dehydrogenase (LDH, EC 1.1.1.27) using the Express Plus (Ciba-Corning Diagnostics Corp., Medfield, MA) automated clinical chemistry analyzer according to the manufacturer's directions. The assays have been previously validated for poultry blood samples.

The right tibia of the two killed birds per each pen was removed and stored at $-18{ }^{\circ} \mathrm{C}$ to assess the total ash and mineral content. Tibia ash was determined by removing the adhering tissue, drying the bone at $110^{\circ} \mathrm{C}$ for $12 \mathrm{~h}$ and extraction of fat with ether. The dry fat-free bones were ashed in a muffle furnace at $550{ }^{\circ} \mathrm{C}$ for $3 \mathrm{~h}$. Ash weight was calculated as a percentage of dry fat-free bone weight.

Ten killed birds per treatment were randomly used for intestinal morphometry according to the method of $\mathrm{Yu}$ et al. (1998). Samples (3 cm in length) were taken from the descending duodenum, the middle region of the jejunum, and the ileum region for each bird and placed into $10 \%$ buffered neutral formaldehyde solution ( $\mathrm{pH} 7.2$ to 7.4). After dehydration, the samples were sectioned at $6 \mu \mathrm{m}$, and stained with hematoxylin and eosin. Villus length, crypt depth and thickness of epithelium were measured at $100 \times$ magnification using computer software (Sigma Scan, Jandel Scientific, San Rafael, CA, USA), and the data were used to calculate the ratio of the villus length to the crypt depth. Goblet cell counts were recorded from $5 \mu \mathrm{m}$ sections stained with periodic acidSchiff reagent (Armed Forces Institute of Pathology, 1992). Briefly, tissues were de-paraffinised and hydrated, oxidised in periodic acid $\left(5 \mathrm{~g} \mathrm{~L}^{-1}\right)$ for $5 \mathrm{~min}$, rinsed in distilled water, and placed in Coleman's Schiff reagent (Sigma Chemi- cal Co., St. Louis, MO, USA) for $30 \mathrm{~min}$. After a 15 min rinse in lukewarm tap water, tissues were counterstained in hematoxylin, rinsed, dehydrated, and mounted. Positively stained periodic acid-Schiff cells were enumerated at 10 villi per sample, and the means were utilised for statistical analysis.

Concentrations of tP in feed and excreta were determined calorimetrically using the molybdovanadate method (AOAC, 2007). Concentration of $\mathrm{Ca}$ in feed and digesta determined by Flame Atomic Absorption Spectrophotometer (A Analyst 100, Perkin-Elmer Inc., USA) according to the method of Naumann and Bassler (1976). The crude protein (CP) content $(\mathrm{N} \times 6.25)$ in the diet and digesta samples was determined based on the Kjeldahl method (Schneitz et al., 1998). Diet and ileum titanium (Ti) contents were analysed by standard procedure, using spectrophotometer (Short et al., 1996). Gross energy was determined by adiabatic bomb calorimetry (Gallenkamp Autobomb, London, UK) standardised with benzoic acid (Schneitz et al., 1998). The AME values of the diets were calculated using the following equation (Meng and Slominski, 2005):

$\mathrm{AME}_{\left(\mathrm{kcal} \mathrm{kg}^{-1}\right)}=\mathrm{GE}_{\text {diet }}-\left[\mathrm{GE}_{\text {digesta }} \times\left(M_{\text {diet }} / M_{\text {digesta }}\right)\right]$,

where $\mathrm{GE}_{\text {diet/digesta }}$ is gross energy of diet and digesta and $M_{\text {diet/digesta }}$ is the marker percentage in diet and digesta.

The tibia contents of $\mathrm{Ca}, \mathrm{P}, \mathrm{Mg}$, and $\mathrm{Zn}$ were measured using dry-ashed bone samples following the same procedure of mineral estimation in feed and faeces (AOAC, 2007).

\subsection{Statistical analysis}

The collected data were subjected to analysis of variance (ANOVA) using general linear model (GLM) of SAS (SAS Inst. Inc. Carry, NC, 2001). differences among mean values were assessed by the Tukey-Kramer test (Kramer, 1956). For the different statistical tests, significance was declared at $P<0.05$.

\section{Results}

The mean DWG and DFI were significantly improved by addition of $30 \mathrm{~g} \mathrm{~kg}^{-1}$ of CA in the diet $(P<0.01)$. The positive effect was greater in 7 to 21 than 22 to 42 days of age. Dietary CA at $60 \mathrm{~g} \mathrm{~kg}^{-1}$ significantly suppressed the same parameters as well as F: $\mathrm{G}$ ratio, in particular, during day 7 to 21 of age (Table 2).

Inclusion of 30 and $60 \mathrm{~g} \mathrm{~kg}^{-1}$ of $\mathrm{CA}$ in the diet, significantly increased the relative weight of proventriculus $(P<0.05)$, gizzard $(P<0.01)$ and ileum $(P<0.05)$. The mean RJL $(P<0.01)$ and RIL $(P<0.01)$ was significantly greater in the birds fed with CA-containing diets compared to the control birds (Table 3 ). A significant decrease in $\mathrm{pH}$ values of the gastrointestinal tract (GIT) segment contents was observed as the level of CA in the diet increased $(P<0.01$; Table 3). 
Table 2. Effect of citric acid on daily weight gain (DWG), daily feed intake (DFI) and feed intake per weight gain (F:G) in broiler chicks from 7 to 42 days of age ${ }^{\mathrm{a}}$.

\begin{tabular}{|c|c|c|c|c|c|}
\hline \multirow[t]{2}{*}{ Variable } & \multicolumn{3}{|c|}{ Dietary citric acid $\left(\mathrm{g} \mathrm{kg}^{-1}\right)$} & \multirow[t]{2}{*}{ SEM } & \multirow[t]{2}{*}{$P$ value } \\
\hline & 0 & 30 & 60 & & \\
\hline \multicolumn{6}{|l|}{ DWG $(g)$} \\
\hline 7 to 21 day $^{b}$ & $26.0^{\mathrm{d}}$ & $30.5^{\mathrm{c}}$ & $23.8^{\mathrm{e}}$ & 0.83 & 0.01 \\
\hline 22 to 42 day $^{b}$ & $71.9^{\mathrm{c}}$ & $75.1^{\mathrm{c}}$ & $61.6^{\mathrm{d}}$ & 2.09 & 0.01 \\
\hline 7 to 42 day $^{\mathrm{b}}$ & $43.2^{\mathrm{c}}$ & $45.0^{\mathrm{c}}$ & $36.9^{d}$ & 1.25 & 0.01 \\
\hline \multicolumn{6}{|l|}{ DFI (g) } \\
\hline 7 to 21 day $^{b}$ & $47.6^{\mathrm{d}}$ & $53.8^{\mathrm{c}}$ & $45.2^{\mathrm{e}}$ & 1.03 & 0.01 \\
\hline 22 to 42 day $^{b}$ & $115.0^{\mathrm{c}}$ & $115.5^{\mathrm{c}}$ & $90.3^{d}$ & 2.23 & 0.01 \\
\hline 7 to 42 day ${ }^{b}$ & $88.0^{\mathrm{c}}$ & $90.8^{\mathrm{c}}$ & $72.3^{d}$ & 1.58 & 0.01 \\
\hline \multicolumn{6}{|l|}{$\mathrm{F}: \mathrm{G}\left(\mathrm{g} \mathrm{g}^{-1}\right)$} \\
\hline 7 to 21 day $^{b}$ & $1.83^{\mathrm{cd}}$ & $1.76^{\mathrm{d}}$ & $1.91^{\mathrm{c}}$ & 0.05 & 0.01 \\
\hline 22 to 42 day $^{b}$ & 2.11 & 2.13 & 2.04 & 0.07 & ns \\
\hline 7 to 42 day $^{b}$ & 2.04 & 2.03 & 2.00 & 0.05 & ns \\
\hline
\end{tabular}

a The chicks were fed a typical commercial broiler starter ration for the first 6 days of life. The average initial weights of the chicks at 7-day-old within experimental treatments were similar among the treatments $(135 \pm 5 \mathrm{~g})$. Each value represents the mean of five replicates (10 birds per replicate).

${ }^{\mathrm{b}}$ Days of measured duration period; ns, not significant.

$\mathrm{c}-\mathrm{e}$ Mean values within a column with no common superscript differ significantly from each other $(\mathrm{P}<0.05)$.

The effect of dietary CA on selected blood metabolites are summarised in Table 4. No change in serum biochemical parameters were observed with dietary $\mathrm{CA}$, with the single exception of cholesterol which was significantly lower in the birds receiving diets with $60 \mathrm{~g} \mathrm{~kg}^{-1}$ of CA $(P<0.05)$.

Inclusion of CA in the diet at $60 \mathrm{~g} \mathrm{~kg}^{-1}$ significantly reduced Alkaline phosphatase (ALP) activity $(P<0.05)$ and increased LDH and AST activities $(P<0.01)$ compared with the control birds at day 42 of age (Table 4$)$. A significant decrease in plasma $P(P<0.01)$ and $\mathrm{Fe}(P<0.05)$ concentrations were observed in the birds receiving $60 \mathrm{~g} \mathrm{~kg}^{-1}$ of dietary CA compared with those receiving either 0 or $30 \mathrm{~g} \mathrm{~kg}^{-1}$ of CA (Table 4). The percentage of bursa and thymus was greater in the birds fed diets containing 60 and $30 \mathrm{~g} \mathrm{~kg}^{-1}$ of CA, respectively, compared to the control birds (Fig. 1; $P<0.01)$.The addition of $30 \mathrm{~g} \mathrm{~kg}^{-1}$ of CA into the diet significantly increased tibia $\mathrm{P}$ retention while no positive effect was demonstrated on tibia $\mathrm{Mg}$ and $\mathrm{Zn}$ (Table 5). The $60 \mathrm{~g} \mathrm{~kg}^{-1}$ level of dietary CA significantly lowered the tibia ash as well as retention of $\mathrm{Ca}$ and $\mathrm{P}$ in the same bone.

A significant improvement in ileal digestibility of $\mathrm{CP}$, AME and $\operatorname{tP}(P<0.01)$ without a change in digestibility of $\mathrm{Ca}$ was observed in the birds fed with the diet containing $30 \mathrm{~g} \mathrm{~kg}^{-1}$ of CA (Table 6). However, administration of $\mathrm{CA}$ at $60 \mathrm{~g} \mathrm{~kg}^{-1}$ of the diet significantly reduced the ileal digestibility of $\mathrm{CP}$, AME and $\mathrm{tP}$ at day 30 of age (Table $6 ; P<0.01)$. The results of morphometrical assessment

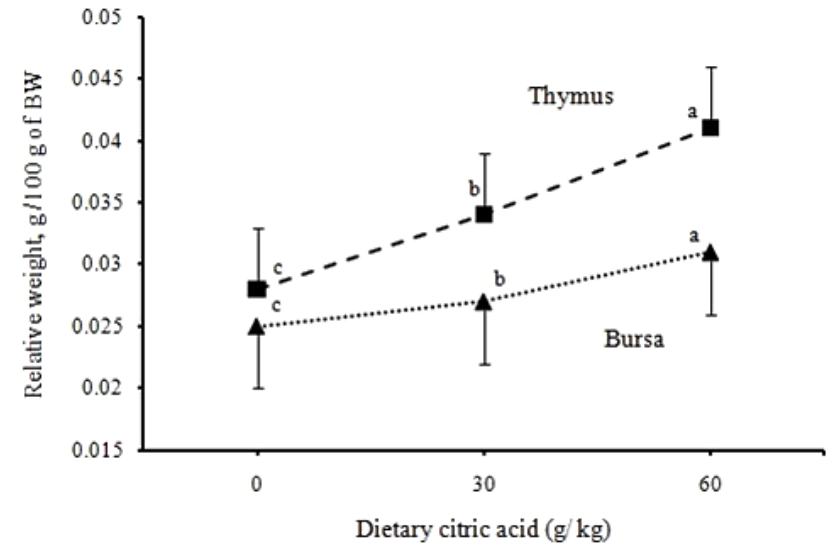

Figure 1. Relative weight of lymphoid organs (Bursa and Thymus) of 42-day-old broiler chickens by dietary inclusion of 30 and $60 \mathrm{~g} \mathrm{~kg}^{-1}$ of citric acid. Values are mean $\pm \operatorname{SE}(n=5)$. Value is significantly different between control and dietary acidification groups $(P<0.05)$.

of small intestine segments are summarised in Table 7. Dietary $\mathrm{CA}$ at $30 \mathrm{~g} \mathrm{~kg}^{-1}$ significantly increased villus length, crypt depth and goblet cell number in duodenum, jejunum and ileum tissue compared with the control birds $(P<0.01)$. The acidified diets also significantly altered the duodenal villi length: crypt depth ratio $(P<0.01)$ and adversely affected villi length: crypt depth ratio in the duodenum $(P<0.01)$. Epithelial thickness in all three segments of the small intestine were significantly lower in the birds fed diets containing $30 \mathrm{~g} \mathrm{~kg}^{-1}$ of CA than other birds $(P<0.01)$.

\section{Discussion}

The improved weight gain, feed intake and feed: gain ratio seen with the inclusion of $3 \% \mathrm{CA}$ in broiler diets in the current study are in agreement with previous reports (Boling et al., 2000; Boling-Frankenbach et al., 2001). The improved performance may be due to decreased $\mathrm{pH}$ of the gut segment contents, the positive effect on gut size and morphometry as well as increased nutrient digestibility (Nourmohammadi et al., 2012). The main objectives of the present study were to determine the effects of high dietary levels of CA $\left(60 \mathrm{~g} \mathrm{~kg}^{-1}\right)$ in broiler chickens. Our results revealed that $60 \mathrm{~g} \mathrm{~kg}^{-1}$ of CA suppressed all productive parameters, a phenomenon which we call "acidic stress". The undesirable zootechnical indices of the birds due to addition of $60 \mathrm{~g} \mathrm{~kg}^{-1}$ of CA into the diet are indicated by negative gut morphometrical parameters, reduced nutrient digestibility and bone mineralisation and the disrupted liver function of the birds. These criteria demonstrate a significant reduction in the metabolism of the birds. Boling-Frankenbach et al. (2001) indicated that 40 and $60 \mathrm{~g}$ $\mathrm{CA} \mathrm{kg}^{-1}$ of diet improved tibia ash but the $60 \mathrm{~g} \mathrm{~kg}^{-1}$ suppressed growth performance. They suggested that a dietary level of $6 \%$ CA may be too high for diets containing $0.45 \%$ 
Table 3. Effect of dietary citric acid on weight percentage and pH of contents in certain gastrointestinal tract (GIT) segments of 42-day-old broiler chickens ${ }^{\mathrm{a}}$.

\begin{tabular}{|c|c|c|c|c|c|}
\hline \multirow[t]{2}{*}{ Variable $^{\mathrm{b}}$} & \multicolumn{3}{|c|}{ Dietary CA $\left(\mathrm{g} \mathrm{kg}^{-1}\right)$} & \multirow[t]{2}{*}{ SEM } & \multirow[t]{2}{*}{$P$ value } \\
\hline & 0 & 30 & 60 & & \\
\hline \multicolumn{6}{|l|}{ GIT segments (g $100 \mathrm{~g}^{-1} \mathrm{BW}$ ) } \\
\hline Proventriculus (g $100 \mathrm{~g}^{-1} \mathrm{BW}$ ) & $0.45^{\mathrm{d}}$ & $0.47^{\mathrm{cd}}$ & $0.50^{\mathrm{e}}$ & 0.25 & 0.05 \\
\hline Gizzard $\left(\mathrm{g} 100 \mathrm{~g}^{-1} \mathrm{BW}\right)$ & $1.57^{\mathrm{d}}$ & $1.88^{\mathrm{e}}$ & $1.91^{\mathrm{e}}$ & 1.07 & 0.01 \\
\hline RIW (g $\left.100 \mathrm{~g}^{-1} \mathrm{BW}\right)$ & $4.51^{\mathrm{cd}}$ & $4.06^{\mathrm{d}}$ & $4.69^{\mathrm{e}}$ & 0.14 & 0.05 \\
\hline RJL (cm $\left.100 \mathrm{~g}^{-1} \mathrm{BW}\right)$ & $5.01^{\mathrm{d}}$ & $5.12^{\mathrm{d}}$ & $5.75^{\mathrm{e}}$ & 0.10 & 0.01 \\
\hline RIL (cm $\left.100 \mathrm{~g}^{-1} \mathrm{BW}\right)$ & $4.50^{\mathrm{d}}$ & $4.55^{\mathrm{d}}$ & $5.14^{\mathrm{e}}$ & 0.09 & 0.01 \\
\hline \multicolumn{6}{|c|}{$\mathrm{pH}$ values in content of GIT segments } \\
\hline Crop & $5.17^{\mathrm{c}}$ & $5.00^{\mathrm{d}}$ & $4.89^{\mathrm{e}}$ & 0.012 & 0.01 \\
\hline Gizzard & $3.21^{\mathrm{c}}$ & $3.19^{\mathrm{c}}$ & $3.09^{\mathrm{d}}$ & 0.006 & 0.01 \\
\hline Duodenum & $5.80^{\mathrm{c}}$ & $5.79^{\mathrm{c}}$ & $5.71^{\mathrm{d}}$ & 0.003 & 0.01 \\
\hline Jejunum & $6.63^{\mathrm{c}}$ & $6.49^{\mathrm{d}}$ & $6.23^{\mathrm{e}}$ & 0.007 & 0.01 \\
\hline Ileum & $7.22^{\mathrm{c}}$ & $7.21^{\mathrm{c}}$ & $7.16^{\mathrm{d}}$ & 0.004 & 0.01 \\
\hline
\end{tabular}

a Each value represents the mean of 10 observations (five replicates $\times$ two birds per replicate).

$\mathrm{b}$ RIW, relative intestinal weight; RJL, relative jejunum length; RIL, relative ileum length.

$\mathrm{c}-\mathrm{e}$ Mean values within a column with no common superscript differ significantly from each other $(P<0.05)$; ns, not significant.

Table 4. Effect of citric acid on select blood parameters and serum enzyme activities ${ }^{\mathrm{a}}$.

\begin{tabular}{|c|c|c|c|c|c|}
\hline \multirow[t]{2}{*}{ Variable } & \multicolumn{3}{|c|}{ Dietary CA $\left(\mathrm{g} \mathrm{kg}^{-1}\right)$} & \multirow[t]{2}{*}{ SEM } & \multirow[t]{2}{*}{$P$ value } \\
\hline & 0 & 30 & 60 & & \\
\hline \multicolumn{6}{|l|}{ Blood metabolites } \\
\hline Urea $\left(\mathrm{mg} \mathrm{dL}^{-1}\right)$ & 2.17 & 2.44 & 2.89 & 0.58 & ns \\
\hline Cholesterol $\left(\mathrm{mg} \mathrm{dL}^{-1}\right)$ & $136.44^{\mathrm{bc}}$ & $137.83^{b}$ & $129.72^{\mathrm{c}}$ & 3.26 & 0.05 \\
\hline Triglycerides $\left(\mathrm{mg} \mathrm{dL}^{-1}\right)$ & 43.39 & 43.72 & 43.33 & 2.61 & ns \\
\hline Total protein $\left(\mathrm{g} \mathrm{dL}^{-1}\right)$ & 2.15 & 2.19 & 2.10 & 0.13 & ns \\
\hline \multicolumn{6}{|l|}{ Serum enzyme activities ${ }^{\mathrm{d}}$} \\
\hline $\operatorname{ALP}\left(\mathrm{UL}^{-1}\right)$ & $2740.11^{\mathrm{b}}$ & $2600.55^{\mathrm{bc}}$ & $2519.44^{\mathrm{c}}$ & 90.80 & 0.05 \\
\hline $\operatorname{AST}\left(\mathrm{UL}^{-1}\right)$ & $222.39^{c}$ & $252.89^{b}$ & $273.44^{\mathrm{b}}$ & 13.29 & 0.01 \\
\hline $\operatorname{ALT}\left(\mathrm{UL}^{-1}\right)$ & 1.75 & 1.64 & 1.60 & 0.09 & ns \\
\hline $\mathrm{LDH}\left(\mathrm{UL}^{-1}\right)$ & $1876.50^{\mathrm{c}}$ & $1831.67^{\mathrm{c}}$ & $2184.39^{\mathrm{b}}$ & 71.24 & 0.01 \\
\hline \multicolumn{6}{|l|}{ Plasma minerals } \\
\hline Calcium $\left(\mathrm{mg} \mathrm{dL}^{-1}\right)$ & 10.11 & 9.94 & 9.96 & 0.23 & ns \\
\hline $\mathrm{P}\left(\mathrm{mg} \mathrm{dL}^{-1}\right)$ & $6.01^{\mathrm{b}}$ & $6.16^{\mathrm{b}}$ & $5.58^{\mathrm{c}}$ & 0.14 & 0.01 \\
\hline $\operatorname{Mg}\left(\mathrm{mg} \mathrm{dL}^{-1}\right)$ & 2.13 & 2.04 & 1.92 & 0.10 & ns \\
\hline $\mathrm{Fe}\left(\mu \mathrm{gdL}{ }^{-1}\right)$ & $1251.39^{b c}$ & $1278.55^{\mathrm{b}}$ & $1146.94^{\mathrm{c}}$ & 55.51 & 0.05 \\
\hline $\mathrm{Zn}\left(\mu \mathrm{g} \mathrm{dL^{-1 }}\right)$ & 249.55 & 288.39 & 272.28 & 32.51 & $\mathrm{~ns}$ \\
\hline
\end{tabular}

${ }^{\text {a } E a c h ~ v a l u e ~ r e p r e s e n t s ~ t h e ~ m e a n ~ o f ~} 10$ observations (five replicates $\times$ two birds per replicate).

${ }^{\mathrm{b}-\mathrm{c}}$ Mean values within a column with no common superscript differ significantly from each other $(P<0.05)$; ns, not significant.

dALP, alkaline phosphatise; AST, aspartate aminotransferase; ALT, alanine aminotransferase; LDH, lactate dehydrogenase.

available phosphorous. The mechanism of action of CA on $\mathrm{P}$ availability is not well defined. It has been speculated that $\mathrm{CA}$ could bind $\mathrm{Ca}$, with a concomitant reduction in their inhibitory effects on intestinal phytic acid hydrolysis (Centeno et al., 2007). Citric acid has been evaluated numerous times for its efficacy in improving productive performance; however, very little work with CA has investigated its efficacy for improving immune response and mineral utilisation by broiler chickens. 
Table 5. Effect of citric acid on bone mineralisation in broiler chicks $^{\mathrm{a}}$.

\begin{tabular}{llllll}
\hline Variable & \multicolumn{3}{c}{ Dietary CA $\left(\mathrm{g} \mathrm{kg}^{-1}\right)$} & \multirow{2}{*}{ SEM } & $P$ value \\
\cline { 2 - 4 } & 0 & 30 & 60 & & \\
\hline Tibia ash (\%) & $46.6^{\mathrm{bc}}$ & $47.7^{\mathrm{b}}$ & $45.9^{\mathrm{c}}$ & 0.64 & 0.01 \\
Calcium (\%) & $37.8^{\mathrm{b}}$ & $38.2^{\mathrm{b}}$ & $37.0^{\mathrm{c}}$ & 0.21 & 0.01 \\
Phosphorus (\%) & $18.2^{\mathrm{c}}$ & $18.3^{\mathrm{b}}$ & $18.2^{\mathrm{c}}$ & 0.03 & 0.01 \\
Mg (\%) & 0.80 & 0.79 & 0.79 & 0.01 & $\mathrm{~ns}$ \\
$\mathrm{Zn}\left(\mathrm{mg} \mathrm{g}^{-1}\right)$ & 342 & 347 & 346 & 3.35 & $\mathrm{~ns}$ \\
\hline
\end{tabular}

${ }^{a}$ Each value represents the mean of 10 observations (five replicates $\times$ two birds per replicate).

$\mathrm{b}-\mathrm{c}$ Mean values within a column with no common superscript differ significantly from each other $(P<0.05)$; ns, not significant.

Table 6. Effect of citric acid on ileal digestibility of select nutrients in broiler chicks ${ }^{\mathrm{a}}$

\begin{tabular}{llllll}
\hline Variable & \multicolumn{3}{c}{ Dietary CA $\left(\mathrm{g} \mathrm{kg}^{-1}\right)$} & \multirow{2}{*}{ SEM } & \multirow{2}{*}{$P$ value } \\
\cline { 2 - 4 } & 0 & 30 & 60 & & \\
\hline $\mathrm{CP}(\%)$ & $83.22^{\mathrm{d}}$ & $84.17^{\mathrm{c}}$ & $77.86^{\mathrm{e}}$ & 0.16 & 0.01 \\
$\mathrm{AME}, \mathrm{kcal} \mathrm{kg}^{-1}$ & $2.717^{\mathrm{d}}$ & $2.796^{\mathrm{c}}$ & $2.679^{\mathrm{e}}$ & 0.19 & 0.01 \\
$\mathrm{Ca}(\%)$ & 59.90 & 60.03 & 59.86 & 0.43 & $\mathrm{~ns}$ \\
$\mathrm{tP}(\%)$ & $41.81^{\mathrm{d}}$ & $42.94^{\mathrm{c}}$ & $36.98^{\mathrm{e}}$ & 0.33 & 0.01 \\
\hline
\end{tabular}

${ }^{\mathrm{a}}$ Each value represents the mean of 15 observations (five replicates $\times 3$ birds per replicate).

${ }^{\mathrm{b}} \mathrm{CP}$, crude protein; AME, apparent metabolisable energy; tP, total phosphorus.

$\mathrm{c}-\mathrm{e}$ Mean values within a column with no common superscript differ significantly from each other $(P<0.05)$; ns, not significant.

A study by Boling et al. (2000) showed that dietary CA (40 and $60 \mathrm{~g} \mathrm{~kg}^{-1}$ ) effectively improved phytate phosphorus utilisation in chicks. They showed that chicks fed diets supplemented with $60 \mathrm{~g} \mathrm{~kg}^{-1}$ of citrate had a $43 \%$ increase in tibia ash and a $22 \%$ increase in weight gain compared to the chicks consuming a non-supplemented diet. Boling et al. (2000) observed increased $\mathrm{Zn}$ utilisation and tibia $\mathrm{Zn}$ content by addition of $60 \mathrm{~g} \mathrm{~kg}^{-1}$ of CA in broiler chicks. In contrast to the above data, dietary $\mathrm{CA}$ at $60 \mathrm{~g} \mathrm{~kg}^{-1}$ compared to the $30 \mathrm{~g} \mathrm{~kg}^{-1}$ further improved the size of the GIT and decreased the $\mathrm{pH}$ of the contents of the gut segments. These changes do not support the idea of acidic stress, as the positive effect of acidified diets usually resulted in an increased size of intestinal segments and decreased $\mathrm{pH}$ value in the contents of the gut segments (Abdel-Fattah et al., 2008).

It seems that over-acidification of the gut content was responsible for the adverse effects of dietary CA on gut size and morphometry as well as lowered nutrient digestibility and absorption. Moreover, the inconsistent changes in blood metabolites and the increased thymus and bursa percentage seen with the higher level of dietary CA in comparison with the lower levels are confusing and not in harmony with the idea of acidic stress. Cave (1984) reported that high dietary levels of CA decreased palatability of feed whereas at low levels it increased feed intake in avian species. Nourmoham-
Table 7. Effect of citric acid on intestinal morphology of broiler chicks ${ }^{\mathrm{a}}$.

\begin{tabular}{|c|c|c|c|c|c|}
\hline \multirow[t]{2}{*}{ Variable } & \multicolumn{3}{|c|}{ Dietary CA $\left(\mathrm{g} \mathrm{kg}^{-1}\right)$} & \multirow[t]{2}{*}{ SEM } & \multirow[t]{2}{*}{$P$ value } \\
\hline & 0 & 30 & 60 & & \\
\hline \multicolumn{6}{|l|}{ Duodenum } \\
\hline Villus length $(\mu \mathrm{m})$ & $1234^{\mathrm{c}}$ & $1348^{\mathrm{b}}$ & $1343^{b}$ & 1.3 & 0.01 \\
\hline Crypt depth $(\mu \mathrm{m})$ & $177^{\mathrm{c}}$ & $182^{\mathrm{b}}$ & $183^{\mathrm{b}}$ & 0.6 & 0.01 \\
\hline Ratio $^{\mathrm{e}}$ & $6.96^{\mathrm{c}}$ & $7.41^{b}$ & $7.37^{b}$ & 0.02 & 0.01 \\
\hline Epithelial thickness $(\mu \mathrm{m})$ & $54^{\mathrm{b}}$ & $52^{\mathrm{c}}$ & $54^{\mathrm{b}}$ & 0.22 & 0.05 \\
\hline Goblet cell number & $9.39^{c}$ & $11.30^{\mathrm{b}}$ & $11.31^{\mathrm{b}}$ & 0.05 & 0.01 \\
\hline \multicolumn{6}{|l|}{ Jejunum } \\
\hline Villus length $(\mu \mathrm{m})$ & $1117^{\mathrm{c}}$ & $1204^{\mathrm{b}}$ & $1200^{\mathrm{b}}$ & 1.3 & 0.01 \\
\hline Crypt depth $(\mu \mathrm{m})$ & $155^{\mathrm{c}}$ & $162^{\mathrm{b}}$ & $161^{\mathrm{b}}$ & 1.1 & 0.01 \\
\hline Ratio $^{b}$ & $7.19^{\mathrm{c}}$ & $7.43^{b}$ & $7.44^{\mathrm{b}}$ & 0.05 & 0.01 \\
\hline Epithelial thickness $(\mu \mathrm{m})$ & $36^{\mathrm{b}}$ & $32^{\mathrm{c}}$ & $36^{\mathrm{b}}$ & 0.32 & 0.01 \\
\hline Goblet cell number & $10.32^{\mathrm{c}}$ & $11.99^{\mathrm{b}}$ & $12.08^{\mathrm{b}}$ & 0.07 & 0.01 \\
\hline \multicolumn{6}{|l|}{ Ileum } \\
\hline Villus length $(\mu \mathrm{m})$ & $761^{\mathrm{c}}$ & $831^{\mathrm{b}}$ & $820^{\mathrm{b}}$ & 5.6 & 0.01 \\
\hline Crypt depth $(\mu \mathrm{m})$ & $148^{\mathrm{c}}$ & $156^{\mathrm{b}}$ & $157^{\mathrm{b}}$ & 1.8 & 0.01 \\
\hline Ratio $^{b}$ & 5.15 & 5.32 & 5.25 & 0.06 & ns \\
\hline Epithelial thickness $(\mu \mathrm{m})$ & $34^{\mathrm{b}}$ & $31^{\mathrm{c}}$ & $33^{b}$ & 0.28 & 0.01 \\
\hline Goblet cell number & $9.78^{\mathrm{c}}$ & $11.58^{\mathrm{b}}$ & $11.73^{\mathrm{b}}$ & 0.17 & 0.01 \\
\hline
\end{tabular}

${ }^{a}$ Each value represents the mean of 10 observations (five replicates $\times$ two birds per replicate).

$\mathrm{b}-\mathrm{c}$ Mean values within a column with no common superscript differ significantly from each other $(P<0.05)$; ns, not significant.

${ }^{\mathrm{e}}$ Ratio of villus length to crypt depth.

madi et al. (2012) showed that inclusion of $60 \mathrm{~g} \mathrm{~kg}^{-1} \mathrm{CA}$ decreased $\mathrm{BW}, \mathrm{BW}$ gain and plasma $P$ concentration. Salgado et al. (2011) concluded that addition of $50 \mathrm{~g} \mathrm{~kg}^{-1} \mathrm{CA}$ into diet also promotes the growth performance of young broiler chickens; however, CA increased serum AST levels and decreased ALT activity. Islam (2012) reported that the dietary inclusion of CA at $7.5 \%$ did not cause any signs of toxicity but significantly suppressed the growth of the birds. A dosimetry study for determination of optimum CA level in broiler diets demonstrated that up to $60 \mathrm{~g} \mathrm{~kg}^{-1} \mathrm{CA}$ maintained live weight, but feed intake was reduced by $15 \mathrm{~g} \mathrm{~kg}^{-1}$ and feed conversion efficiency increased up to $60 \mathrm{~g} \mathrm{~kg}^{-1}$ (Islam, 2012).

It is speculated that the negative consequences of high dietary CA may result from acidosis of blood. Acidosis occurs when blood $\mathrm{pH}$ drops below 7.4. Dietary changes are critical in the occurrence of acidosis (Remer, 2000). Changes from the normal acid-base balance towards acidosis resulted in suppressed performance (Bushinsky et al., 1999). Also, it has been recognised that high AST activity usually occurs during severe stress, followed by increased levels of glucocorticoids in serum (Gabriel et al., 2012). This may be related to the fact that a high level of CA may act as a stressor, causing dysfunction of internal organs (e.g. kidney, liver, heart, and skeletal muscle). 


\section{Conclusions}

In conclusion, the addition of $30 \mathrm{~g} \mathrm{~kg}^{-1}$ of $\mathrm{CA}$ to the diet improved almost all zootechnical indices as well as nutrient retention in broiler chickens, whereas $60 \mathrm{~g} \mathrm{~kg}^{-1}$ of CA in the diet resulted in retarded growth, suppressed nutrients digestibility, and disrupted liver and kidney functions. Such alterations in digestion, absorption and metabolism could be the direct result of over-acidification of the diet, gut contents and consequently blood. The term "acidic stress" may be useful to describe this physiological condition.

Edited by: S. Maak

Reviewed by: two anonymous referees

\section{References}

Abdel-Fattah, L. M., El-Sanhoury, M. H., El-Mednay, N. M., and Abdel-Azeem, F.: Thyroid activity, some blood constituents, organs morphology and performance of broiler chicks fed supplemental organic acids, J. Poult. Sci., 7, 215-222, 2008.

Anjum, M. S. and Chaudhry, A. S.: Using enzymes and organic acids in broiler diets, J. Poult. Sci., 47, 97-105, 2010.

AOAC: Official methods of analysis (18th ed), Association of Official Analytical Chemists, Inc., Arlington, Virginia, USA, 2007.

Aviagen: Ross 308 broiler management guide, available at: http: //en.aviagen.com/ross-308/, 2011.

Aydin, A., Pekel, A. Y., Issa, G., Demirel, G., and Patterson, P. H.: Effects of dietary copper, citric acid, and microbial phytase on digesta $\mathrm{pH}$ and ileal and carcass microbiota of broiler chickens fed a low available phosphorus diet, J. Appl. Poultry Res., 19, 422-431, 2010.

Boling, S. D., Webel, D. M., Mavromichalis, I., Parsons, C. M., and Baker, D. H.: The effects of citric acid on phytate-phosphorus utilization in young chicks and pigs, J. Anim. Sci., 78, 682-689, 2000.

Boling-Frankenbach, S. D., Snow, J. L., Parsons, C. M., and Baker, D. H.: The effect of citric acid on the calcium and phosphorus requirements of chicks fed corn-soybean meal diets, Poultry Sci., 80, 783-788, 2001.

Brenes, A., Viveros, A., Arija, I., Centeno, C., Pizarro, M., and Braro, C.: The effect of citric acid and microbial phytase on mineral utilization in broiler chicks, Anim. Feed Sci. Tech., 110, 201-219, 2003.

Bushinsky, D. A., Chabala, J. M., Gavrilov, K. L., and Levi-Setti, R.: Effects of in vivo metabolic acidosis on midcortical bone ion composition, Am. J. Physiol., 277, 813-819, 1999.

Cave, N. A. G.: Effect of dietary propionic and lactic acid on feed intake by chicks, Poultry Sci. 63, 131-134, 1984.

Centeno, C., Arija, I., Viveros, A., and Brenes, A.: Effects of citric acid and microbial phytase on amino acid digestibility in broiler chickens, Brit. Poultry Sci., 48, 469-479, 2007.

Esmaeilipour, O., Shivazad, M., Moravej, H., Aminzadeh, S., Rezaian, M., and van Krimpen, M. M.: Effects of xylanase and citric acid on the performance, nutrient retention, and characteristics of gastrointestinal tract of broilers fed low-phosphorus wheat-based diets, Poultry Sci., 90, 1975-1982, 2011.

Gabriel, U. U., Akinrotimi, O. A., and Ariweriokuma, V. S.: Changes in metabolic enzymes activities in selected organs and tissue of clariasgariepinus exposed to cypermethrin, J. Environ. Eng. Technol., 1, 13-19, 2012.

Iranian Council of Animal Care.: Guide to the Care and Use of Experimental Animals, Vol. 1, Isfahan University of Technology, Isfahan, Iran, 1995.

Islam, K. M. S.: Use of citric acid in broiler diets, World Poultry Sci. J., 68, 104-118, 2012.

Kirchgessner, M. and Roth, F. X.: Fumaric acid as a feed additive in pig nutrition, Pig News Information, 3, 259-263, 1982.

Kramer, C. Y.: Extension of multiple range tests to group means with unequal numbers of replications, Biometry, 12, 307-310, 1956.

Meng, X. and Slominski, B. A.: Nutritive values of corn, soybean meal, canola meal and peas for broiler chickens as affected by a multycarbohydrase preparation of cell wall degrading enzymes, Poultry Sci., 84, 1242-1251, 2005.

Naumann, C. and Bassler, R.: VDLUFA-Methodenbuch, Vol. III. Die chemische Untersuchung von Futtermitteln, VDLUFA Verlag, Darmstadt, Germany, 1976.

Nourmohammadi, R., Hosseini, S. M., Farhangfar, H., and Bashtani, M.: Effect of citric acid and microbial phytase enzyme on ileal digestibility of some nutrients in broiler chicks fed cornsoybean meal diets, Ital. J. Anim. Sci., 11, 36-40, 2012.

Pileggi, V. J., Luca, H. F. D., Cramer, J. W., and Steenbock, H.: Citrate in the prevention of rickets in rats, Arch. Biochem. Biophys., 60, 52-57, 1956.

Remer, T.: Influence of diet on acid-base balance, Seminar in Dialysis, 13, 221-226, 2000.

Salgado-Tránsito, L., Del Río-García, J. C., Arjona-Román, J. L., Moreno-Martínez, E., and Méndez-Albores, A.: Effect of citric acid supplemented diets on aflatoxin degradation, growth performance and serum parameters in broiler chickens, Arch. Med. Vet., 43, 215-222, 2011.

SAS: Statistical Analysis Systems user's guide (8th ed.), SAS Institute Inc., Cary, NC, USA, 2001.

Schneitz, C., Kiiskinen, T., Toivonen, V., and Nasi, M.: Effect of BROILACT on the physicochemical conditions and nutrient digestibility in the gastrointestinal tract of broilers, Poultry Sci., 77, 426-432, 1998.

Shohl, A. T.: The effect of the acid-base content of the diet upon the production and cure of rickets with special reference to citrates, J. Nutr., 14, 69-83, 1937.

Short, F. J., Gorton, P., Wiseman, J., and Boorman, K. N.: Determination of titanium dioxide added as an inert marker in chicken digestibility studies, Anim. Feed Sci. Tech., 59, 215-221, 1996.

Thompson, J. L. and Hinton, M.: Antibacterial activity of formic and propionic acids in the diet of hens on salmonellas in the crop, Brit. Poultry Sci., 38, 59-65, 1997.

Viveros, A., Brenes, A., Arija, I., and Centeno, C.: Effects of microbial phytase supplementation on mineral utilization and serum enzyme activities in broiler chicks fed different levels of phosphorus, Poultry Sci., 81, 1172-1183, 2002.

Windisch, W., Schedle, K., Plitzner, C., and Kroismayr, A.: Use of phytogenic products as feed additives for swine and poultry, J. Anim. Sci., 86, 140-148, 2008.

Yu, B., Tsai, C. C., Hsu, J. C., and Chiou, P. W. S.: Effect of different sources of dietary fibre on growth performance, intestinal morphology and caecal carbohydrases of domestic geese, Brit. Poultry Sci., 39, 560-567, 1998. 